\title{
PENGARUH FAMILY SUPPORT GROUP TERHADAP KEPATUHAN DIET PASIEN DIABETES MELITUS DI WILAYAH KERJA PUSKESMAS KOTA TANGERANG
}

\author{
Musripah $^{1}$, Nana Supriyatna ${ }^{2}$, SigitMulyono $^{3}$ \\ ${ }_{1,2,3}$ Universitas Muhammadiyah Jakarta \\ E-mail :musripah75dhea@gmail.com
}

\begin{abstract}
Abstrak
Diabetes Mellitus merupakan penyakit yang tidak dapat disembuhkan dan jika tidak ditangani dengan benar dapat mengakibatkan berbagai macam komplikasi penyakit seperti stroke, jantung koroner, gagal ginjal, kebutaan, luka diabetes sampai dengan amputasi organ. Intervensi family support group bertujuan supaya pasien diabetes mellitus dapat merasakan dukungan dan perhatian dari keluarganya yang membuat mereka dapat menjani hidup yang berkualitas sekalipun dengan menderita penyakit diabetes mellitus, dan tidak terjadi komplikasi.Penelitian ini bertujuan menganalisis pengaruh family support group terhadap kepatuhan diet pada pasien diabetes mellitus. Rancangan penelitian ini menggunakan quasi eksperimen dengan pendekatan pre dan post with control group dengan jumlah sampel $(\mathrm{n})=64$ yang dibagi menjadi dua kelompok yaitu intervensi dan kontrol dengan masing-masing 32 responden. Analisis data menggunakan uji Wilcoxon menunjukkan perbedaan bermakna family support group terhadap kepatuhan diet pada pasien Diabetes Mellitus sebelum dan sesudah mengikuti Family Support Group dengan p value $=0,000(\mathrm{p}<0,05)$ dan tidak terdapat perbedaan bermakna kepatuhan diet pada pasien Diabetes Mellitus sebelum dan sesudah tanpa diberikan family support group dengan $p=0,616$ ( $p>0,05)$. Hasil penelitian ini diharapkan dapat menjadikan family support group sebagai salah satu intervensi keperawatan untuk meningkatkan kepatuhan diet pada pasien diabetes mellitus.
\end{abstract}

Kata Kunci : diabetes Mellitus, family support group, kepatuhan diet

\begin{abstract}
Diabetes Mellitus is a disease that cannot be cured and if it is not handled properly, it can lead to various complications such as stroke, coronary heart disease, kidney failure, blindness, diabetes wounds and organ amputation. The family support group intervention aims so that diabetes mellitus patients can feel the support and attention of their families so that they can lead a quality life even with diabetes mellitus, and there are no complications. This study aims to analyze the effect of family support groups on dietary compliance in patients with diabetes mellitus. The research design used a quasi' experimental approach with pre and post control group with a sample size $(n)=64$ which was divided into two groups, namely intervention and control with 32 respondents each. Data analysis using the Wilcoxon test showed significant differences in family support group dietary adherence in Diabetes Mellitus patients before and after joining the Family Support Group with $p$ value $=0.000(p<0.05)$ and there was no significant difference in dietary adherence in Diabetes Mellitus patients before and after without being given a family support group with $p=$ 0.616 ( $p>0.05$ ). The results of this study are expected to make family support groups as one of the nursing interventions to improve dietary compliance in diabetes mellitus patients
\end{abstract}

Keywords: diabetes mellitus, diet compliance, family support group

\section{Pendahuluan}

Penyakit Diabetes Melitus merupakan

penyakit degeneratif dengan dengan

manifestasi tingginya kadar gula darah

biasanya masyarakat awam menyebutnya dengan nama penyakit kencing manis, Penyebab dari diabetes mellitus tipe 2 adalah karena adanya gannguan hormon insulin yang tidak bekerja dengan maksimal atau bisa juga disebabkan karena retensi insulin atau dari 
keduanya (Soelistijo, Novia, Rudijanto, et al., 2015).

Indonesia merupakan peringkat ke-6 dunia dengan jumlah penderita diabetes (diabetesi) terbesar, yaitu sebanyak 10,3 juta jiwa, data tersebut diperoleh dari International Diabetes Federation (IDF) Atlas tahun 2017. Pada tahun 2018 menunjukkan prevalensi penyandang diabetes naik mejadi $8,5 \%$, dari 6,9\% (Riskesdas 2013. Penyakit diabetes merupakan penyebab kematian terbesar nomor tiga di Indonesia setelah Stroke $(21,1 \%)$ dan penyakit Jantung Koroner (12,9\%) dengan presentase sebesar 6,7\%, (Kementerian Kesehatan, 2014). Prevalensi Diabetes Mellitus menurut Provinsi di Indonesia pada tahun 2018, menunjukkan bahwa prevalensi Diabetes Mellitus tertinggi terdapat di Provinsi DKI Jakarta yaitu sebesar $2,6 \%$ dan prevalensi terendah terdapat di Provinsi Nusa Tenggara Timur yaitu sebesar 0,6\%, prevalensi Diabetes Mellitus di Provinsi Jawa Barat sebesar 1,3\% sedangakan prevalensi Diabetes Mellitus di Provinsi Banten sebesar 1,7 \% (Riskesdas, 2018).

Masalah kejenuhan pada pasien DM harus segera diatasi agar tidak menyebabkan komplikasi. Penanganan Diabetes Mellitus yang terus menerus membuat pasien DM kadang merasa bosan dan menyebabkan ketidakpatuhan terhadap penatalaksanaan. Hal ini menyebabkan munculnya beberapa gejala psikologis. Diabetes burnout syndrom adalah respon psikologis distress yang frustasi terhadap penyakit Diabetes Mellitus yang dideritanya dan bosan dengan perawatan diri penyakit Diabetes Mellitus. Gejalanya sering ditandai dengan mengabaikan kadar gula darah dan mengabaikan diet yang harus dijalaninya. Hal ini akan membuat pasien merasa marah terhadap dirinya sendiri karena penyakitnya dan merasa terbebani dengan kadar gula darahnya. Hal ini akan berpengaruh terhadap tindakan mandiri pasien dalam melakukan perawatan Diabetes Mellitusnya. Faktor penting dalam pengendalian diabetes adalah pemahaman tentang penyakit dan perubahan gaya hidup. Oleh sebab itu dibutuhkan dukungan dari keluarga penyandang diabetes.

Family Support Group merupakan kegiatan pertemuan antara keluarga yang anggota keluarganya menderita DM, dimana mereka dapat berbagi perasaan, pengalaman dan harapan mereka umumnya dilakukan dua minggu sekali ( Sri Lestari, 2012). Family Support Group diharapkan berpengaruh terhadap anggota keluarga yang menderita DM terhadap kepatuhan menjalankan programpengobatan sesuai anjuran dokter atau tenaga kesehatan. Dukungan dari keluarga dapat memberikan efek yang positif terhadap psikologis, kesehatan fisik, dan 
kualitas hidup pasien (Chung, Cho, Chung., 2013).

American Diabetes Association, 2017, dukungan bisa diberikan dalam bentuk menemani berobat, bersama-sama ikutmengubah pola makan menjadi lebih sehat, berolahraga bersama, atau mengingatkan untuk mengontrol kadar gula darah. Dukungan dari orang terdekat, tanpa dukungan keluarga pasien akan merasa terisolasi.

Berdasarkan penelitian lain menggambarkan bahwa dukungan yang berasal dari orang terdekat yaitu keluarga yang kurang baik memberikan dampak pada tingkat kepatuhan minum obat yang rendah terhadap pasien diabetes sehingga dapat berakibat buruknya kontrol glikemik (Mayberry, 2012). Dari hasil penelitian yang dilakukan oleh Wijayanti, 2015, diperoleh data 85,7 persen responden mengaku butuh dukungan dari keluarga dan teman terdekatnya agar dapat menjalankan gaya hidup sehat dan mengontrol penyakitnya yang terdiri dari dukungan instrument, dukungan informasi, dukungan penghargaan atau penilaian, dukungan emosional. Pemahaman keluarga tentang pengelolaan diabetes serta dukungan keluarga dapat mempengaruhi terkendalinya kadar HbA1c (Muhibuddin, Sugiarto dan Wujoso,2016).
Oleh sebab itu peneliti tertarik untuk melakukan penelitian tentang pengaruh family support group terhadap kepatuhan diet pada usia dewasa dengan diabetes melitus.

\section{Tinjauan teori}

Diabetes melitus adalah penyakit metabolik dengan karakteristik kadargula darah tinggi yang disebabkan karena produksiinsulin yang terganggu atau terjadi retensi insulin dan atau kerja insulin atau terjadi pada kedua duanya (ADA,2017).

Family Support Group adalah suatu metode Therapeutic Community yang terdiri dari sekelompok atau perkumpulan dari keluarga penyandang diabetes mellitus.

\section{Metodologi}

Jenis Penelitian ini adalah quasi eksperimen pre dan post with control group. populasi dalam penelitian ini adalah semua penderita Diabetes Melitus usia $30-65$ tahun di Puskesmas Gembor dan Puskesmas Priuk Kota Tangerang yaitu berjumlah 343 pasien, sedangkan jumlah sampel pada tiap kelompok adalah 32 responden. Teknik pengambilan sampel adalah teknik non probability sampling yaitu purposive sampling. 
Kriteria inklusi pada penelitian ini adalah:Pasien Diabetes yang tinggal serumah dengan keluarga ( anak, suami, istri, keluarga dekat ), Memahami bahasa indonesia dan bisa diajak komunikasi verbal, Pasien Diabetes Mellitus yang tidak ada komplikasi. Sedangkan Kriteria eksklusi pada penelitian ini adalah sebagai berikut :Pasien diabetes mellitus yang tidak memiliki keluarga yang tinggal serumah, Pasien diabetes mellitus yang mengundurkan diri sebagai respondendan Pasien diabetes yang tidak termasuk diabetes melitus tipe 1 atau 2

Tempat penelitian ini dilakukan di Puskesmas Gembor dan Puskesmas Priuk Kota Tangerang dan dilakukan selama 5-6 minggu. dimulai pada bulan Juni-Juli 2020

\section{Hasil}

Karakteristik responden pada penelitian ini akan dilihat pada tabel 1 .

Tabel 1 menjelaskan bahwa karakteristik usia pada kelompok intervensi dan kelompok kontrol paling banyak antara usia 46 - 59 tahun. Jenis kelamin pada kelompok intervensi paling banyak adalah perempuan sebanyak $65,6 \%$ dan pada kelompok control paling banyak adalah laki - laki sebanyak 59,38\%. Tingkat pendidkan pada kelompok intervensi paling banyak adalah SMA sebanyak $53,1 \%$ dan pada kelompok control paling banyak SD - SMP sebanyak 65,6\%.

\section{Tabel 1. Distribusi Respoden berdasarkan Usia, Jenis kelamin, Pendidikan, Lama terdiagnosa Diabetes Melitus di Wilayah Puskesmas Kota Tangerang}

\begin{tabular}{|c|c|c|c|c|}
\hline \multirow[t]{2}{*}{ Tariabel } & \multicolumn{2}{|c|}{ Kelomnolinterrensi. } & \multicolumn{2}{|c|}{ KelompokKontrol } \\
\hline & $\mathrm{N}$ & $\%$ & $\mathrm{~N}$ & $\%$ \\
\hline \multicolumn{5}{|l|}{ tsia } \\
\hline 26-45 Tahun & 6 & 18,75 & 2 & 6.25 \\
\hline 46.59 Tahum & 26 & 81,25 & 25 & 78,13 \\
\hline$>60$ Tahum & 0 & 0 & 5 & 15,63 \\
\hline Jumlah & 32 & 100 & 32 & 100 \\
\hline \multicolumn{5}{|l|}{ Jenis Kelamin } \\
\hline Laki-Iaki & 11 & 34,38 & 19 & 59,38 \\
\hline Perempuan & 21 & 65,63 & 13 & 40,63 \\
\hline Jumlah & 32 & 100,0 & 32 & 100,0 \\
\hline \multicolumn{5}{|l|}{ Pendidikan } \\
\hline Rendah (SD-SMP) & 15 & 46,88 & 21 & 65,63 \\
\hline Tinggi (SMA Universitas) & 17 & 53,13 & 11 & 34,38 \\
\hline Jumlah & 32 & 100,0 & 32 & 100,0 \\
\hline \multicolumn{5}{|l|}{ Lama terdiagnosa DM } \\
\hline$<5$ Tahum & 21 & 65,63 & 11 & 34,38 \\
\hline$>5$ Tahum & 11 & 34,38 & 21 & 65,63 \\
\hline Iumlah & 32 & 100,0 & 18 & 100,0 \\
\hline
\end{tabular}

Tabel 2. Distribusi Responden Berdasarkan Kepatuhan Diet Diabetes Melitus pada kelompok intervensi dan kelompok kontrol di Wilayah Kerja Puskesmas Kota Tangerang

\begin{tabular}{|c|c|c|c|c|}
\hline \multirow{3}{*}{ Variabel } & \multicolumn{4}{|c|}{ Kelompok } \\
\hline & \multicolumn{2}{|c|}{ Kelompok Intervensi } & \multicolumn{2}{|c|}{ Kelompok Kontrol } \\
\hline & $\mathrm{N}$ & $\%$ & $\mathrm{~N}$ & $\%$ \\
\hline Kepatuhan Diet & & & & \\
\hline \multicolumn{5}{|l|}{ Melitus sebelum intervensi } \\
\hline Kurang & 16 & 50 & 19 & 59,38 \\
\hline Baik & 16 & 50 & 13 & 40,63 \\
\hline Diet Diabetes & & & & \\
\hline \multicolumn{5}{|l|}{ Melitus setelah intervensi } \\
\hline Kurang & 13 & 40,63 & 25 & 78,13 \\
\hline Baik & 19 & 59,38 & 7 & 21,88 \\
\hline
\end{tabular}

Tabel 2 menjelaskan bahwa kepatuhan diet Diabetes melitus kurang sebelum dilakukan tindakan pada kelompok intervensi sekitar $50 \%$, sedangkan pada kelompok control sebanyak 59,4\%. Kepatuhan diet Diabetes melitus baik setelah dilakukan family support grup pada kelompok intervensi sebanyak $59,4 \%$ dan pada kelompok control sebayak $21,88 \%$ 
Tabel 3. Pengaruh Family Support Group terhadap Kepatuhan Diet Pada Pasien Diabetes Mellitus Sebelum Dan Sesudah Dilakukan Intervensi Pada Kelompok Intervensi di Wilayah Kerja Puskesmas Kota Tangerang

\begin{tabular}{lcccc}
\hline $\begin{array}{c}\text { Kelompok } \\
\text { (Intervensi) }\end{array}$ & N & Mean & SD & $\begin{array}{c}\text { P } \\
\text { Value }\end{array}$ \\
\cline { 1 - 4 } Sebelum & 32 & 46,56 & 6,53 & 0,000 \\
Setelah & 32 & 68,28 & 2,16 &
\end{tabular}

Berdasarkan tabel diatas dapat disimpulkan hasil bahwa pada kelompok intervensi ratarata kepatuhan diet pada pasien Diabetes Mellitus sebelum dilakukan intervensi adalah 46,56 sedangkan rata-rata kepatuhan diet pada pasien Diabees Melitus setelah diberikan intervensi adalah 68,28. Hasil statistik uji nilai $p=0,000(p<0,05)$ maka dapat ditarik kesimpulan ada pengaruh Family Support Group terhadap Kepatuhan Diet Pada Pasien Diabetes Melitus sebelum dan sesudah mengikuti Family Support Group pada kelompok intervensi di Wilayah Kerja Puskesmas Kota Tangerang.

Berdasarkan tabel 4 didapatkan hasil bahwa pada kelompok kontrol rata- rata kepatuhan diet pada pasien Diabetes Mellitus pre adalah 52,25 sedangkan rata-rata kepatuhan diet pada pasien Diabetes Mellitus post adalah 53.

Hasil statistik uji Non Parametrik nilai $p=0,616 \quad(\mathrm{p}>0,05) \quad$ maka dapat ditarik kesimpulan tidak ada pengaruh Family Support Group terhadap kepatuhan diet pada pasien Diabetes Mellitus pre dan post pada kelompok kontrol di Wilayah Kerja Puskesmas Kota Tangerang

Tabel 4. Pengaruh Family Support Group terhadap kepatuhan diet pada pasien Diabetes Mellitus pre dan post pada kelompok kontrol di wilayah kerja Puskesmas Kota Tangerang

\begin{tabular}{ccccc}
\hline $\begin{array}{c}\text { Kelompok } \\
(\text { Kontrol) }\end{array}$ & N & Mean & SD & P Value \\
\cline { 1 - 3 } Sebelum & 32 & 52,25 & 15,927 & 0,616 \\
\cline { 1 - 3 } Setelah & 32 & 53 & 3,38 &
\end{tabular}

.Tabel 5. Perbedaan pengaruh Family Support Group terhadap kepatuhan diet pada pasien Diabetes Mellitus sesudah diberikan intervensi pada kelompok intervensi dan kelompok kontrol

\begin{tabular}{lcccc}
\hline Kelompok & $\mathbf{N}$ & Mean & SD & P Value \\
\hline Intervensi & 32 & 68,28 & 2,16 & 0,000 \\
\cline { 1 - 3 } Kontrol & 32 & 53 & 3,38 &
\end{tabular}

Berdasarkan tabel 5 didapatkan hasil bahwa pada kelompok intervensi rata-rata kepatuhan diet pada pasien Diabetes Mellitus post adalah 68,28 , sedangkan rata-rata kepatuhan diet pada pasien Diabetes Mellitus setelah dilakukan kontrol adalah 53. Hasil statistik uji Non Parametrik ( Mann Whitney) untuk nilai $p=0,000 \quad(p<0,05)$ maka dapat ditarik kesimpulan ada pengaruh Family Support Group terhadap Kepatuhan Diet Pada Pasien Diabetes Mellitus yang diberikan intervensi Family Support Group dan yang tidak diberikan intervensi prolanis di Wilayah Kerja Puskesmas Kota Tangerang 


\section{Pembahasan}

\section{Interpretasi Karakterstik}

Dari hasil penelitian ini diketahui rata-rata responden berusia 46-59 tahun. Kelompok usia yang menjadi faktor risiko diabetes adalah usia lebih dari 45 tahun, Prevalensi DM akan meningkat dengan bertambahnya usia, hal ini dikarenakan semakin lanjut usia maka pengeluaran insulin oleh pankreas juga akan semakin berkurang. (Mihardja, 2010).

Hal ini sesuai dengan hasil penelitian yang dilakukan (Suryadi, 2014) yang menyebutkan bahwa pada penyakit Diabetes Melitus Tipe II usia lebih dari 45 tahun dapat menyebabkan resiko terjadinya penyakit Diabetes Melitus dan usia yang memicu pengeluaran hormonhormon yang dapat terjadi ketidakstabilan kadar gula darah akibatnya kerja insulin mengalami penurunan.

Dalam penelitian ini rata-rata responden yang berjenis kelamin perempuan lebih banyak dari laki - laki (65,63\%). Penelitian ini tidak sejalan dengan pendapat, Hilawe et al.,2013 yang menerangkan bahwa pria lebih mungkin untuk mengidap diabetes dibandingkan dengan perempuan. Hal ini menunjukkan bahwa jenis kelamin tidak mempengaruhi terhadap kejadian diabetes melitus.
Pada penelitian ini hampir sebagian besar responden berpendidikan rendah yaitu sebesar $65,63 \%$

Hal ini sesuai dengan hasil penelitian (Andi et al, 2015) yang menyebutkan bahwa tingkat pengetahuan tinggi memiliki peluang untuk lebih patuh dalam menjalankan diet Diabetes Melitus dibandingkan responden yang memiliki tingkat pengetahuan rendah. Pendidikan menurut Notoatmodjo (2010), berpengaruh pada perilaku sehat yaitu perilaku-perilaku yang berkaitan dengan upaya atau kegiatan seseorang untuk mempertahankan dan meningkatkan kesehatannya.

Pada penelitian ini hampir sebagian besar responden terdiagnosa Diabetes Melitus menunjukan $65,63 \%<$ dari 5 tahun. Penelitian ini ini sejalan dengan hasil penelitian Susanti paling banyak menderita Diabetes Melitus $\pm 1-5$ tahun dan $>5$ tahun, semakin lama pasien terdiagnosis Diabetes Mellitus, maka pasien sering mendapatkan informasi penyuluhan tentang diet dan pengobatan, sehingga akan mempengaruhi dalam mengambil keputusan untuk melakukan tindakan. 
Gambaran tingkat kepatuhan diet pada pasien Diabetes Mellitus sebelum dilakukan intervensi Family Support Group.

Hasil penelitian didapatkan $50 \%$ responden memiliki kepatuhan diet kurang. Menurut Sandjaja, dkk (2010) diet Diabetes Melitus adalah suatu terapi farmakologis yang sangat direkomendasikan bagi penyandang Diabetes Melitus.

Diet Diabetes Melitus ini prinsipnya melakukan pegaturan pola makan yang didasarkan pada status gizi diabetes dan melakukan modifikasi diet berdasarkan kebutuhan individual.) Dalam kepatuhan diet diabetes mellitus ada 3J yang harus diketahui dan dilaksanakan oleh penderita diabetes mellitus, yaitu jumlah makanan, jenis makanan dan jadwal makanan

Pemerintah membuat program pengelolaan penyakit kronis (PROLANIS) sebagai upaya mencapai kualitas hidup yang optimal bagi penyandang diabetes mellitus. Untuk meningkatkan kepatuhan salah satu upaya yang dapat dilakukan dengan support family grup. Sesuai penelitian yang dilakukan oleh Rosland Piette, Lyles et al., 2013; Badr, Elmabsout, dan Denna, 2014. Dukungan keluarga berpengaruh terhadap diet yang optimal bagi pasien diabetes mellitus,

\section{Gambaran Kepatuhan Diet pada pasien Diabetes Mellitus sesudah dilakukan intervensi Family Suopport Group.}

Hasil penelitian menunjukan bahwa setelah dilakukan Family Support Group ada peningkatankepatuhan diet dari responden yaitu 59,38\%. Yang artinya ada peningkatan kepatuhan yang bermakna. Hasil ini sejalan dengan penelitian yang dilakukan oleh Wahyuni ( 2011) terjadi “ peningkatan yang signifikan kemampuan keluarga setelah diberikan supportif group therapy

Didalam Family Suopport Group pendekatan yang petugas kesehatan tidak saja memberikan nasehat, mengajar atau memberi perintah tetapi lebih pada membantu seseorang, mendukung dan menganjurkan individu untuk melakukan hal-hal yang diinstrusikan oleh pemberi layanan kesehatan. (National Health Service, 2014). Dengan Family Suopport Group maka pasien akan secara aktif diberi kebebasan terbuka menyampaikan masalah yang dihadapi, saling diskusi dan memberi dukungan sehingga pasien akan lebih termotivasi untuk menjalankan perawatan dan pengobatan.

\section{Pengaruh Family Support Group terhadap kepatuhan diet pada pasien Diabetes Mellitus pada kelompok intervensi}

Hasil penelitian didapatkan bahwa ada pengaruh yang bermakna terhadap kepatuhan 
diet pada pasien Diabetes Mellitus sebelum dan setelah dilakukan Family Support Group dengan nilai $\mathrm{P}$ value $0,000<0,05$. Dibandingkan dengan kelompok yang tidak diberi intervensi tidak ada perubahan sehingga. pada kurun waktu dan dengan pengukuran yang sama membuktikan bahwa terjadi perubahan pada responden yang diberikan intervensi.

Hal ini sejalan dengan penelitian oleh Amelia, A S Wahyuni $R$ A Ariga' Felicia and Preveena, tahun 2018. Penelitian menunjukkan bahwa sebagian besar pasien (60\%) dengan diabetes tipe 2 di Amplas PHC memiliki dukungan keluarga yang mendukung. Dukungan keluarga adalah sikap, tindakan dan penerimaan keluarga terhadap orang sakit.

Dukungan dapat datang dari orang lain (orang tua, anak-anak, suami, istri atau kerabat dekat) dengan subjek di mana bentuk dukungan adalah informasi, perilaku atau materi tertentu yang dapat membuat individu merasa dirawat dan dicintai . Kemenkes (2011) kepatuhan adalah suatu bentuk perilaku yang timbul karena adanya interaksi antara petugas kesehatan dengan pasien sehingga pasien mengetahui rencana dengan segala konsekuensinya sehingga menyetujui rencana tersebut serta melaksanakannya.

\section{Pengaruh Family Support Group terhadap} kepatuhan diet pada pasien Diabetes Mellitus pre dan post pada kelompok kontrol

Hasil penelitian menunjukan dari uji Non Parametrik ( Mann Whitney ) nilai $p=0,616$ (p>0,05) bahwa pada kelompok yang tidak diberi intervensi tidak ada perubahan yang bermakna.

Hasil penelitian ini sejalan dengan penelitian yang dilakukan oleh Datak (2018) yang menyatakan bahwa kelompok kontrol yang tidak mendapatkan intervensi.Kemenkes (2011) kepatuhan adalah suatu bentuk perilaku yang timbul karena adanya interaksi antara petugas kesehatan dengan pasien sehingga pasien mengetahui rencana dengan segala konsekuensinya sehingga menyetujui rencana tersebut serta melaksanakannya.

Penelitian Wahyuni ( 2011) yang mengatakan bahwa terjadi“" peningkatan yang signifikan kemampuan keluarga setelah diberikan supportif group therapy"

\section{Perbedaan Pengaruh Family Support} Group terhadap kepatuhan diet pada pasien Diabetes Mellitus Sesudah Diberikan Intervensi pada Kelompok Intervensi dan Kelompok Kontrol

Hasil penelitian menunjukan bahwa terdapat perbedaan mean pada kelompok intervensi 
dan kontrol sebesar 15,25 setelah dilakukan intervensi health coaching dan hasil uji statistic didapatkan nilai $0,000<0,05$ artinya ada perbedaan yang bermakna antara kelompok intervensi dan kelompok control setelah diberikan family support group terhadap kepatuhan diet pada pasien Diabetes Melitus.

Didalam Intervensi family support group seluruh keluarga yang memiliki anggota keluarga dengan Diabetes Mellitus diberikan keleluasaan dalam menyampaikan setiap masalah kesehatan yang dihadapi sehingga akan muncul sikap terbuka dan lebih percaya diri dalam merawat keluarganya selain itu juga pasien saling memberi dukungan danmotivasi dalam menjalani program pengobatan yang diajalani.

Family Support Group mengajarkan keluarga untuk dapat memahami masalah, dan menerima kenyataan, mengakui, mengerti dan mendorong untuk mengikuti program pemulihan penyakit Diabetes Melitus, sehingga keluarga mengetahui bagaimana mereka bersikap terhadap keluargamya. (Lestari, 2012)

\section{Kesimpulan}

Dari hasil penelitian dapat diketahui bahwa :

1. Sebagian besar responden merupakan usia dewasa madya baik pada kelompok intervensi maupun kelompok kontrol, berjenis kelamin perempuan Musripah, Pengaruh Family Support Group Terhadap Kepatuhan Diet Pasien Diabetes Melitus Di Wilayah Kerja Puskesmas Kota Tangerang | 25 dan pada kelompok kontrol sebagian besar berjenis kelamin laki -laki.tingkat pendidikan responden pada kelompok intervensi berpendidikan tinggi sedangkan pada pada kelompok kontrol sebagian besar berpendidikan rendah.

2. Tingkat kepatuhan diet diabetes mellitus diberikan intervensi berimbang, sedangkan pada kelompokkontrol sebagian besar kurang patuh terhadap diet diabetes mellitus.

3. Pada kelompok intervensi ada pengaruh pada tingkat kepatuhan diet pada pasien Diabetes Mellitus sebelum dan setelah dilakukan family support group

4. Pada kepatuhan diet pada pasien Diabetes Mellitus ada perbedaan mean pada kelompok intervensi dan kontrol sebesar 15,25 setelah dilakukan intervensi family support group dan hasil uji statistic didapatkan nilai $0,000<0,05$ artinya ada perbedaan yang bermakna antara kelompok intervensi dan kelompok kontrol setelah diberikan Family Support Group terhadap kepatuhan diet pada pasien Diabetes Melitus.

\section{Saran}

Bagi Institusi pelayanan

Perlu adanya sosialisasi pada intitusi pelayanan dalam hal ini adalah dinas kesehatan dan puskesmas sebagai salah satu pada kelompok intervensi sebelum 
intervensi yang cukup efektif dalam pemberian edukasi dimana lebih berfokus pada mengajarkan, melatih dan memotivasi pasien dalam menjalani program pengobatanya.

\section{Intitusi Pendidikan}

menjadikan hasil penelitian ini menjadi materi pada saat pengabdian masyarakat serta dijadikan sebagai bukti ilmiah bahwa "family support group " terhadap kepatuhan diet terhadap pasien Diabetes Mellitus merupakan terapi non farmakologis dalam pengendalian dan pencegahan terhadap komplikasi DiabetesMellitus.

\section{Pengembangan Ilmu Keperawatan}

Hasil penelitian ini diharapkan dapat menjadikan family support group sebagai salah satu intervensi keperawatan untuk meningkatkan kepatuhan diet pada pasien diabetes mellitus.

\section{Ucapan terimkasih}

Terima Kasih yang tak terhingga penulis ucapkan kepadaSeluruh Dosen dan staf Program pasca Sarjana Fakultas Ilmu Keperawatan Universitas Muhammadiyah Jakarta, Responden dan semua pihak yang telah banyak membantu dalam proses pembuatan tesis ini.

\section{Referensi}

Alligood MR. (2017). Pakar Teori
Keperawatan. Editor Edisi Indonesia.Elsevier.

Arifin \& Santi Damyanti.(2015). Hubungan Dukungan Keluarga Dengan Kepatuhan Dietdiabetes Melitus Tipe 2 Di Poli Penyakit Dalam RSUP Dr. Soeradji Tirtonegoro klaten.Jurnal Keperawatan Respati Vol. II No 2 September 2015

http://nursingjurnal.respati.ac.id/inde x.php/JKRY/article/download/170/79.

Arisman. (2013). Obesitas, Diabetes Melitus,dan Dislipidemia: Konsep: Teori, dan Penanganan Aplikatif Seri Buku Ajar Ilmu Gizi. Jakarta: EGC.

Bachtiyar, B., Dewi, Erti., Aini, L. (2015). Pengaruh terapi suportif: kelompok terhadap perubahan harga diri klien TB Paru di Kecamatan Umbulsari. EJurnal Pustaka Kesehatan Vol 3 (no.2).

Dahlan, S. (2016).Statistic untuk kedokteran dan kesehatan, seri 1 edisi 6. Jakarta. Epidemiologi Indonesia

Dewi, Erti., Hamid, A., Mustikasari. (2012). Pengaruh terapi kelompok suportif terhadap tingkat ansietas keluarga dalam merawat anak tunagrahita.Jurnal Keperawatan Soedirman volume 7 No. 1.

Friedman, M. (2010).Keperawatan keluarga teori dan praktek edisi 5.Jakarta:EGC

Hasbi, M. (2012) .Analisis Faktor yang Berhubungan dengan Kepatuha Penderita

Hastono, S. P. (2018). Analisis data pada bidang kesehatan. Jakarta: Fakultas Kesehatan Masyarakat Universitas Indonesia.

Irianto Koes,(2014). Epidemiologi Penyakit Menular dan Tidak Menular Panduan Klinis, Bandung.Alfabet. 
Kementrian Kesehatan RI. 2018. Profil kesehatan indonesia 2017. Jakarta:Kemenkes RI. Diakses pada tanggal 31 Januari 2019 dari http:// www.depkes.go.id /resources/ download/pusdatin/profil kesehatan indonesia/Profil-Kesehatan-Indonesiatahun-2017.pdf.

Notoatmodjo.(2014). Promosi kesehatan dan ilmu perilaku.Jakarta :Rineka cipta.

Nursalam ( 2015 ). Metodologi Penelitian. Jakarta: Salemba Medika.

PERKENI, (2015), Pengelolaan dan Pencegahan Diabetes MelitusTipe2 di Indonesia, PERKENI,Jakarta.

Profile Dinas Kesehatan Kota Tangerang, 2019

Pratiwi, Denia. 2011. Pengaruh Konseling Obat terhadap Kepatuhan Pasien Hipertensi di Poliklinik Khusus Rumah Sakit Umum Pusat DR.M.Djamil Padang.Tesis.Program Pascasarjana Universitas Andalas Padang.

Rangga Aji Nur Wahid ( 2016), Pengaruh Pendidikan Kesehatan Diabetes Self Management Education ( DSME) Terhadap Kadar Gula Darah Pasien Diabetes Tipe II di Prolanis Puskesmas Gajahan Surakarta.
Skrpsi.

Ramadona, Ade. 2011. Pengaruh Konseling Obat terhadap Kepatuhan Pasien DiabetesMellitus Tipe 2 di Poliklinik Khusus Rumah Sakit Umum Pusat DR.M.Djamil Padang.Tesis. Program Pasca Sarjana. Universitas AndalasPadang.

Riset Kesehatan Dasar ( Riskesda, 2013 ), Badan Penelitian Dan Pengembangan Kesehatan Kementrian RI.

Riset Kesehatan Dasar ( Riskesda, 2018 ), Badan Penelitian Dan Pengembangan Kesehatan Kementrian RI

Rikesdas.(2018). Hasil utama riskesdas.Kementerian kesehatan badan dan pengembangan kesehatan,Hal 1- 88.

Sugiyono, ( 2011. Statistik Untuk Penelitian. Bandung;CV. Alfabeta

Wawan,\& Dewi. (2011). Teori \& pengukuran pengetahuan, sikap, dan perilaku manusia. Yogyakarta: NuhaMedika.

Yoshepin P. Tjahjono ( 2013). Pengaruh Edukasi Melalui Media Visual Buku Ilustrasi Terhadap Pengetahuan dan Kepatuhan Pasien Diabetes Mellitus Tipe 2.Calyptra : Jurnal Ilmiah Mahasiswa Universitas Surabaya Vo. 2, No.1 